\title{
Rediscovery, taxonomic and conservation status of the threatened catfish Listrura camposi (Miranda-Ribeiro) (Siluriformes: Trichomycteridae)
}

\author{
Leandro Villa-Verde ${ }^{1}$, Sergio M. Q. Lima ${ }^{2,3}$, Pedro Hollanda Carvalho ${ }^{2,4}$ \\ and Mário C. C. de Pinna ${ }^{4}$
}

\begin{abstract}
The genus Listrura, Glanapteryginae, currently comprises six valid species of small and elongated trichomycterid catfishes that inhabit coastal plains of Southern and Southeastern Brazil. As primarily fossorial dwellers, species of the genus display unusual morphological adaptations and restricted habitats, which make these fishes particularly susceptible to environmental disturbance. Listrura camposi is poorly known and ranked as a Critically Endangered catfish species, according to current Brazilian list of threatened species. Description of the species was based on a single specimen collected in 1940, and for seven decades no additional specimens were reported. As a consequence, basic information about the species is unavailable. Recently, a population of L. camposi was found inhabiting a small stream tributary to rio Ribeira de Iguape basin, São Paulo State, relatively close to the type locality. On the basis of newly collected material, the species is redescribed and the first data on its habitat and ecology are presented. Conservation status is also discussed.
\end{abstract}

O gênero Listrura, Glanapteryginae, compreende atualmente seis espécies válidas de bagres pequenos e alongados que habitam as baixadas costeiras do Sul e Sudeste do Brasil. Principalmente de hábitos fossoriais, as espécies do gênero apresentam adaptações morfológicas incomuns e habitat restrito, o que torna estes peixes particularmente suscetíveis a distúrbios ambientais. Listrura camposi é pouco conhecida e considerada uma espécie Criticamente em Perigo, segundo as mais recentes listas brasileiras de espécies ameaçadas. A descrição da espécie foi baseada em um único exemplar coletado em 1940 e por sete décadas nenhum espécime adicional foi relatado. Como consequência, informações básicas sobre a espécie estão indisponíveis. Recentemente, uma população de L. camposi foi encontrada habitando um pequeno córrego tributário da bacia rio Ribeira de Iguape, estado de São Paulo, relativamente próximo da localidade-tipo. Com base no material coletado recentemente, a espécie é redescrita e os primeiros dados sobre seu habitat e ecologia são apresentados. O estado de conservação também é discutido.

Key words: Atlantic forest, Glanapteryginae, IUCN criteria, rio Ribeira de Iguape basin, Serra do Mar.

\section{Introduction}

Listrura camposi (Miranda-Ribeiro) is a poorly known species belonging to a highly specialized genus of trichomycterids endemic to coastal southeastern drainages of South America. All six species currently included in Listrura de Pinna are unusual in museum collections, in part due to their narrowly specialized habitats and patchy distribution pattern. Species of the genus are interstitial inhabitants of marginal environments, usually with very small water volume and near underground sources. Few or no other fish species occur in the same microhabitat.
Of all species of Listrura, L. camposi is the least known. Its description (Miranda-Ribeiro, 1957) was based on a single specimen collected in 1940 from ribeirão do Poço Grande (tributary to rio Juquiá, itself tributary to rio Ribeira de Iguape) at Juquiá, São Paulo State, Brazil. This species was originally included in the genus Eremophilus Humboldt (Trichomycterinae) by Miranda-Ribeiro (1957), based on the absence of pelvic fin and girdle. Later, de Pinna (1988) demonstrated that E. camposi is, in fact, related to the Glanapteryginae rather than to E. mutisii Humboldt, and described the genus Listrura to accommodate that species plus the newly described L. nematopteryx de Pinna. That

\footnotetext{
${ }^{1}$ Museu Nacional/UFRJ, Setor de Ictiologia, Departamento de Vertebrados. Quinta da Boa Vista s/n, São Cristóvão, 20940-040 Rio de Janeiro, RJ, Brazil. elffobr@yahoo.com.br

${ }^{2}$ Universidade Federal do Rio de Janeiro, Laboratório de Biodiversidade Molecular, Departamento de Genética, Instituto de Biologia. Cidade Universitária, CCS, Bloco A, 21941-470 Rio de Janeiro, RJ, Brazil. hollandacarvalho@gmail.com (PHC)

${ }^{3}$ Universidade Federal do Rio Grande do Norte, Departamento de Botânica, Ecologia e Zoologia, 59978-970, Natal, RN, Brazil. smaialima@gmail.com (SMQL)

${ }^{4}$ Museu de Zoologia, Universidade de São Paulo. Caixa Postal 42494, 04218-970, São Paulo, SP, Brazil. pinna@ib.usp.br (MCCP)
} 
paper included a detailed redescription of $L$. camposi, albeit based solely on the unique type specimen then known.

In 1993, three specimens of Listrura were collected from Ribeirão da Ilha, in a small isolated coastal basin at Florianópolis, Santa Catarina State, Brazil. This population has been identified as L. camposi (e.g. Nico \& de Pinna, 1996; Wosiacki \& de Pinna, 2007; Rosa \& Lima, 2008), but strict confirmation of that identification was impossible due to the scarcity of material of L. camposi from the type locality or surroundings.

In 2007, several specimens (49) unambiguously identified as Listrura camposi were collected from a small shallow stream draining directly to the rio Itariri, itself a tributary to rio Juquiá, rio Ribeira de Iguape basin, município de Pedro de Toledo, São Paulo State. The present paper reports on the rediscovery of this species. Data from the new material form the basis of a redescription of the species including, for the first time, information on intraspecific variation and osteology. The comparative information thus obtained permits a detailed assessment of the taxonomic status of $L$. camposi, along with a revised diagnosis of the species. Field data gathered during collecting activities also for the first time offer habitat information on L. camposi.

\section{Material and Methods}

Measurements were taken according to de Pinna (1988), except for body width, caudal peduncle width, eye diameter, and mouth width, which were taken following Costa (1992). Counts were taken on cleared and stained (CS) specimens according to Taylor and van Dyke (1985), except for number of pectoral-fin rays, which was taken from all available specimens (50). Numbers of dorsal and anal-fin rays include all rays (procurrent plus principal, respectively). Counts of pectoral-fin rays were codified as ' $a / b$ ', which ' $a$ ' and ' $b$ ' indicate ray numbers on each side of body (left and right sides unspecified); numbers in parentheses indicate the number of specimens. Vertebral counts do not include the Weberian complex or the compound caudal centrum. Osteological head terminology follows Datovo \& Bockmann (2010), except for angulo-articular herein interpreted as a coossification between it and retro-articular, following Adriaens et al. (2010). Nomenclature for caudal-skeleton structures follows Bockmann et al. (2004). Laterosensory system terminology follows Arratia \& Huaquín (1995), except for pores 1,2 , and 3 of main lateral line herein interpreted respectively as pore 1 of postotic branch, pores 1 and 2 of main lateral line.

Abbreviations for institutions are: MCP, Museu de Ciências e Tecnologia, Pontifícia Universidade Católica do Rio Grande do Sul, Porto Alegre; MHNCI, Museu de História Natural Capão da Imbuia, Curitiba; MNRJ, Museu Nacional, Universidade Federal do Rio de Janeiro, Rio de Janeiro; MZUSP, Museu de Zoologia, Universidade de São Paulo, São Paulo; and UFRJ, Laboratório de Sistemática e Evolução de Peixes Teleósteos, Universidade Federal do Rio de Janeiro, Rio de Janeiro.

\section{Listrura camposi (Miranda-Ribeiro, 1957) Figs. 1-2}

Eremophilus camposi Miranda-Ribeiro, 1957: 72, fig. Type locality: ribeirão do Poço Grande, tributary to the right bank of rio Juquiá, itself tributary to rio Ribeira, Fazenda Poço Grande, município de Juquiá, São Paulo State, Brazil [ca. $\left.24^{\circ} 15^{\prime} \mathrm{S} 47^{\circ} 37^{\prime} \mathrm{W}\right]$, holotype MZUSP 3426.-MirandaRibeiro, 1962: 1-2, fig. [non Miranda-Ribeiro, 1957; actually Listrura nematopteryx].- Britski, 1969: 206 [Type catalog].de Pinna, 1988: 119 [remarks; synonymy].

Listrura camposi.- de Pinna, 1988: 119, figs. 3, 4 [redescription; phylogenetic relationships; inclusion in Glanapteryginae].Bizerril, 1994: 625 [distribution].- Nico \& de Pinna, 1996: 29 [distribution; habitat notes].- Burgess \& Finley, 1996: 168 [checklist; distribution].- Landim \& Costa, 2002: 154155 [phylogenetic relationships].- de Pinna \& Wosiacki, 2002: 725 [phylogenetic relationships].- de Pinna \& Wosiacki, 2003: 275 [checklist; distribution].- Rosa \& Lima, 2005: 81 [checklist; conservation status].- Villa-Verde \& Costa, 2006: 44 [distribution].- Menezes et al., 2007: 306, fig. [checklist; distribution; conservation status].Wosiacki \& de Pinna, 2007: 74 [checklist; distribution; conservation status].- Ferraris Jr., 2007: 408 [checklist; distribution].- Rosa \& Lima, 2008: 243-244, fig. [checklist; conservation status; distribution; habitat notes].Adriaens et al., 2010: 350 [trichomycterid morphology].Datovo \& Bockmann, 2010: 219-221, table 2, figs. 31, 32 [phylogenetic relationships].- de Pinna \& Kirovsky, 2011: 502 [comparative material].- Villa-Verde et al., 2012: 534 [comparative material].

Listrura campos.- MMA, 2004: 141 [misspelling; conservation status].

Diagnosis. Listrura camposi is distinguished from all congeners by the quadrate bone with an abrupt depression on dorsal margin ( $v s$. depression absent or very slight; Fig. 3 ), and the presence of a vestigial neural arch on the compound caudal centrum ( $v s$. absent; Fig. 4). It differs further from L. tetraradiata Landim \& Costa in having only unbranched rays on the dorsal, anal and pectoral fins (vs. some branched rays present in each of those fins), by the presence of 30-34 dorsal and 26-28 ventral procurrent caudalfin rays (vs. 21-28 and 20-24, respectively), 49-51 total vertebrae (vs. 44-45), and absence of supraorbital canal and respective pore on the laterosensory system (vs. present). Differs further from L. nematopteryx, L. costai Villa-Verde, Lazzarotto \& Lima and L. picinguabae Villa-Verde \& Costa by having three or four (rarely two) pectoral-fin rays ( $v s$. one), and caudal skeleton with hypurals $1+2$ and hypurals $3+4+5$ separate ( $v s$. almost entirely fused; Fig. 4). Differs further from $L$. boticario de Pinna \& Wosiacki by the presence of dorsal fin ( $v s$. absent).

Description. Morphometric data given in Table 1. Body elongate, subcylindrical at anterior portion of trunk, strongly 


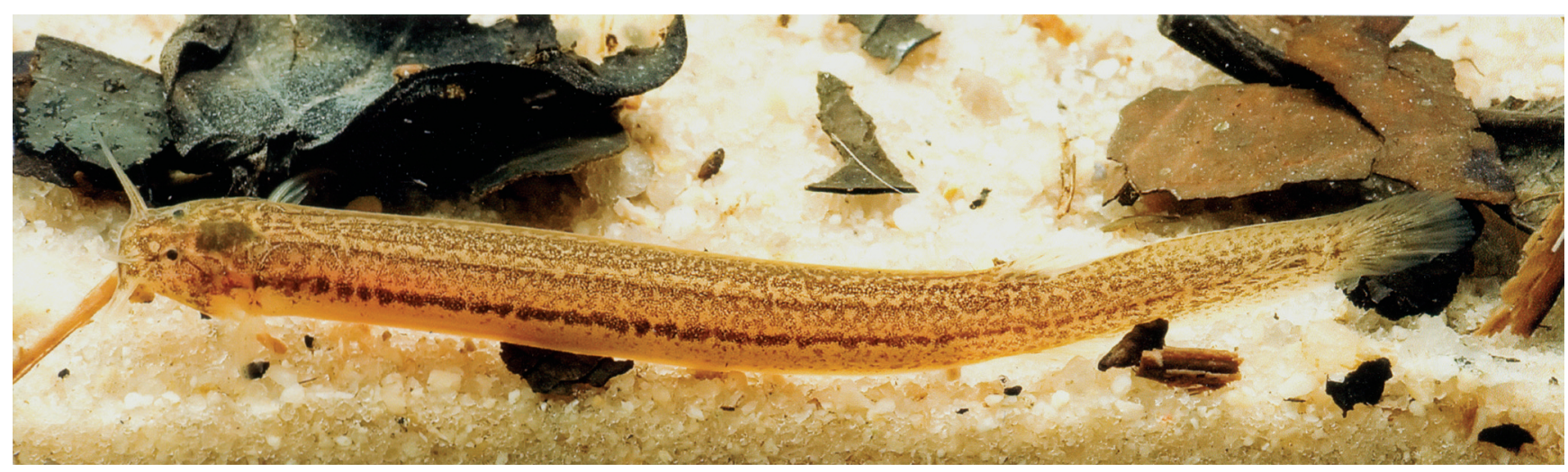

Fig. 1. Listrura camposi, MZUSP 95189, 46.4 mm SL, live specimen; Brazil, São Paulo State, município de Pedro de Toledo. Photo by Cristiano Moreira.

compressed at caudal peduncle. Dorsal and ventral profiles straight. Skin papillae minute.

Head depressed and trapezoidal. Snout blunt and slightly elongate. Mouth subterminal and narrow. Teeth conical, tips pointed and curved. Two rows of teeth in jaw. Premaxillary teeth 18-26; dentary teeth 17-21. Eyes anteriorly located on head, nearer snout tip than to opercular patch of odontodes. Nasal, maxillary and rictal barbels well developed. Tip of nasal barbel reaching between posterior margin of interopercular patch of odontodes and posterior margin of opercular patch of odontodes. Tip of maxillary barbel reaching just beyond posterior margin of opercular patch of odontodes. Tip of rictal barbel reaching between middle of interopercular patch of odontodes and posterior margin of opercular patch of odontodes. Anterior nostril anteriorly at base of nasal barbel. Posterior nostril on anterior half of length between anterior nostril and eye. Interopercular odontodes 11-15, opercular odontodes 8-10; odontodes conical, tips pointed and slightly curved.

Dorsal and anal fins approximately triangular, all rays unbranched. Dorsal-fin origin on posterior half of trunk, at vertical between centra of $32^{\text {nd }}$ and $33^{\text {th }}$ vertebrae. Anal-fin origin at vertical between centra of $33^{\text {rd }}$ and $34^{\text {th }}$ vertebrae, and at vertical through $4^{\text {th }}$ to $6^{\text {th }}$ dorsal-fin ray. Posterior margin of caudal fin rounded; caudal fin extending dorsally and ventrally to posterior margins of dorsal- and anal-fin bases. Pectoral fin triangular; first ray filamentous. Pelvic fin and girdle absent. Dorsal-fin rays 8. Anal-fin rays 8-9. Principal caudal-fin rays 12 , dorsal procurrent rays $31-34$, ventral procurrent rays 26-28. Pectoral-fin rays $3 / 2$ (3), 3/3 (28), 3/4 (10), or 4/4 (8); holotype 3/3. Ribs 3-4. Total vertebrae 49-51. Branchial membranes attached only at anteriormost point of isthmus. Branchiostegal rays 6 .

Laterosensory system extremely reduced, without supraorbital, infraorbital, and otic canals. Preopercular canal extremely reduced to single pore, at vertical through anterior margin of opercular patch of odontodes (Fig. 5a). Postotic

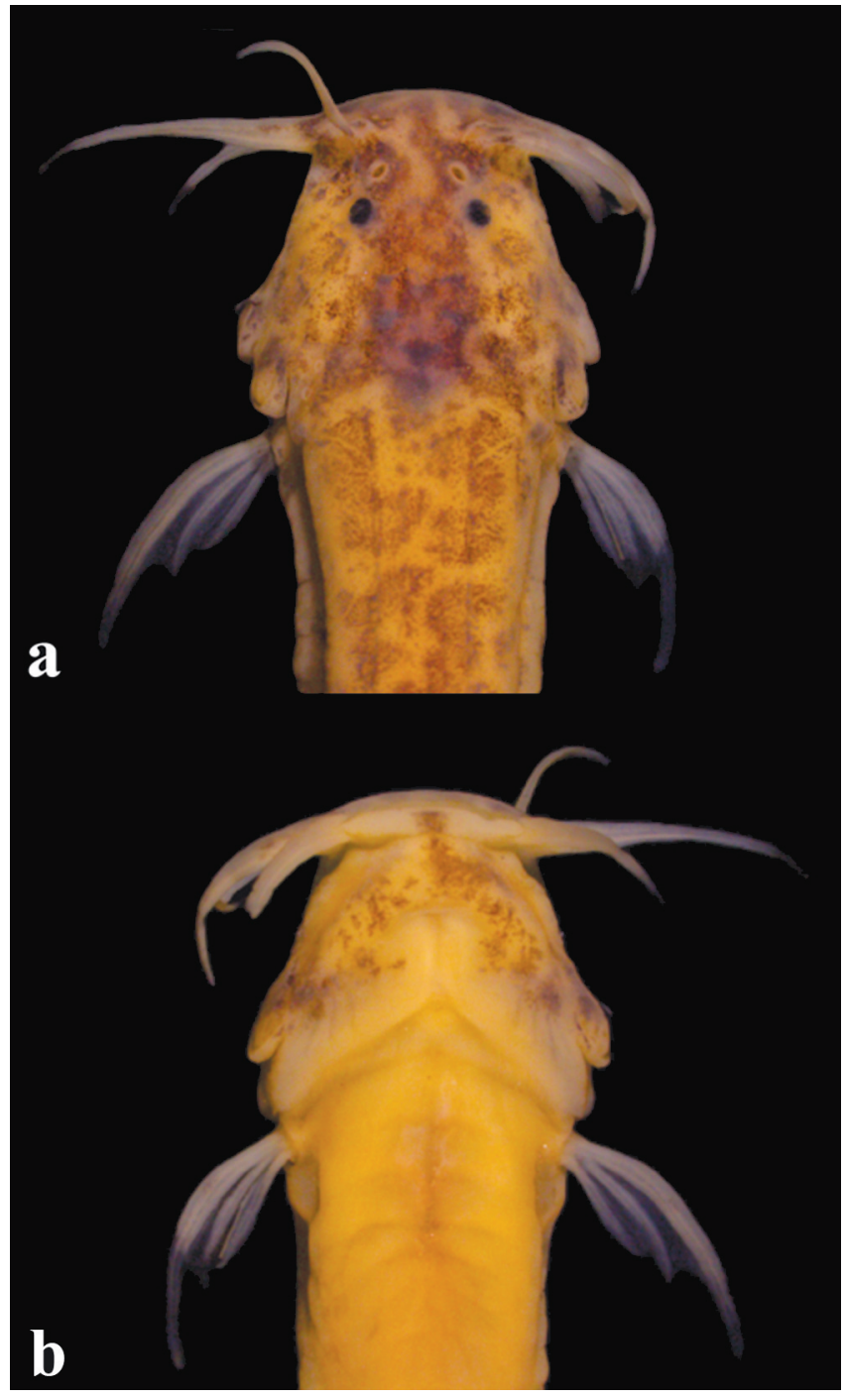

Fig. 2. Head detail of Listrura camposi, MZUSP 95189, 46.4 $\mathrm{mm} \mathrm{SL}$ in (a) dorsal and (b) ventral views. 


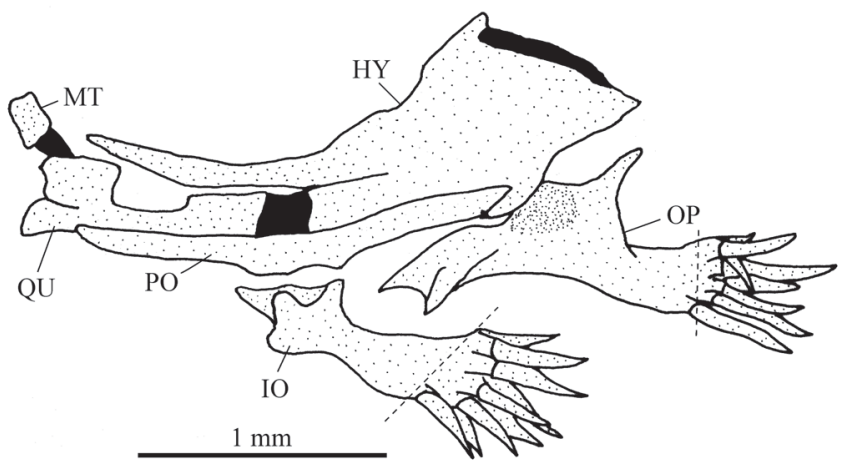

Fig. 3. Suspensorium and opercular apparatus of Listrura camposi, MNRJ 37023, $35.7 \mathrm{~mm}$ SL, left side: lateral view. Dashed lines indicate the inclination of the opercular and interopercular paths of odontodes. Legends: HY hyomandibula, IO - interopercle, MT - metapterygoid, OP opercle, $\mathrm{PO}$ - preopercle, QU - quadrate.

canal with one pore, corresponding to pterotic branch, at vertical just posterior to opercular patch of odontodes. Main lateral line short, with two pores: anteriormost largest, at vertical just posterior to pectoral-fin base; posteriormost below and just posterior to first pore.

Osteology. Anterior cornua of mesethmoid straight (Fig. 5a). Lateral ethmoid with small lateral projection. Frontal triangular; cranial fontanel absent. Parieto-supraoccipital with lateral processes enclosed to sphenotic. Prootic, pterosphenoid and sphenotic entirely fused to each other. Vomer without posterior process (bottle-shaped). Parasphenoid with small posterior process, reaching to anteriormost tip of basioccipital. Pterotic with lateral laminar expansion. Basioccipital and exoccipital fully fused to each other and posteriorly fused to Weberian capsule. Co-ossified basioccipital and exoccipital approximately triangular. Weberian capsule with small lateral opening to each side.

Autopalatine nearly square with dorsally-curved posterolateral process (Fig. 5a). Premaxilla triangular. Maxilla elongate. Antorbital short and club-shape. Sesamoid supraorbital extremely reduced.

Dentary triangular with teeth reaching half distance between coronoid process and mesial tip (Fig. 5b). Meckel cartilage square; extension of area in contact with dentary similar to that in contact with angulo-articular (see Discussion below). Angulo-articular and retro-articular entirely fused. Coronoid process with large cartilage on dentary portion (coronomaxillar cartilage, following Datovo \& Bockmann, 2010).

Hyomandibula with elongated and narrow anteriororiented process (Fig. 3). Quadrate elongate with anterodorsal laminar projection and with abrupt depression on dorsal margin forming U-shape (see Discussion below). Metapterygoid very reduced and articulating only with

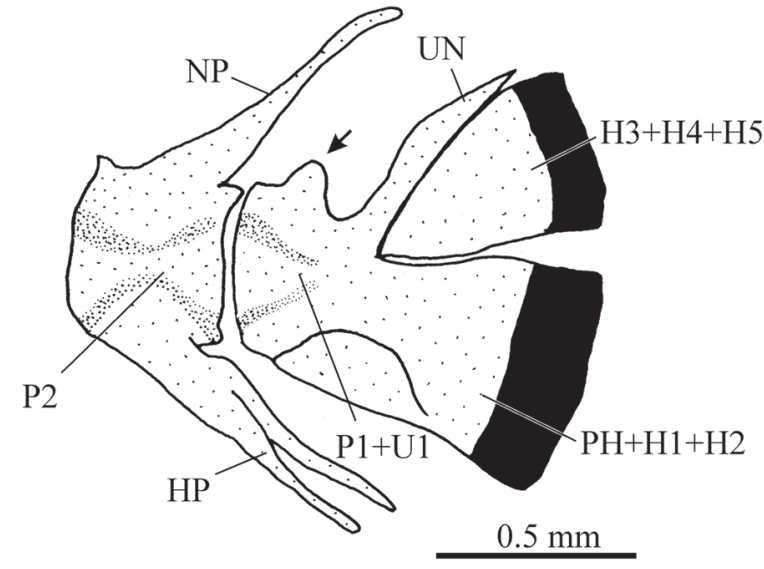

Fig. 4. Caudal skeleton of Listrura camposi, MNRJ 37023, $35.7 \mathrm{~mm} \mathrm{SL}$, left side: lateral view. The arrow indicates the vestigial neural arch of preural-1 centrum. Legends: $\mathrm{H} 3+\mathrm{H} 4+\mathrm{H} 5$ - fused hypural 3-hypural 4-hypural 5, HS - hemal spine, NS - neural spine, P1+U1 - fused preural 1-ural 1, P2 preural centrum 2, $\mathrm{PH}+\mathrm{H} 1+\mathrm{H} 2$ - fused parhypural -hypural 1hypural 2, UN - uroneural.

anterodorsal portion of quadrate through cartilaginous block. Preopercle elongate. Opercular odontodes disposed on vertical plane at posteriormost process of opercle. Interopercular odontodes disposed obliquely on posterior tip of interopercle, far behind from articular condyle for preopercle (see Discussion below).

Table 1. Morphometric data of holotype and 26 additional specimens of Listrura camposi. Data of holotype from de Pinna (1988), except those indicated by asterisks.

\begin{tabular}{lccc}
\hline & Holotype & Non-types \\
\cline { 2 - 4 } & MZUSP 3426 & Range & Mean \\
\hline Standard length (mm) & 37.2 & $27.6-50.0$ & 36.2 \\
Head length (mm) & 4.6 & $3.5-5.4$ & 4.5 \\
\multicolumn{1}{c}{ Total length } & 112.0 & $107.9-118.5$ & 112.5 \\
Body depth & 9.0 & $7.9-11.7$ & 10.4 \\
Caudal peduncle depth & 8.0 & $8.4-12.7$ & 11.0 \\
Body width & $2.9^{*}$ & $4.0-7.2$ & 5.3 \\
Caudal peduncle width & $1.5^{*}$ & $1.3-2.6$ & 1.8 \\
Caudal peduncle length & 22.0 & $18.4-25.1$ & 21.6 \\
Dorsal-fin base length & 4.0 & $3.7-6.5$ & 5.2 \\
Anal-fin base length & 5.0 & $4.4-7.3$ & 6.0 \\
Pectoral-fin length & 8.0 & $6.7-14.0$ & 9.9 \\
Predorsal length & 73.0 & $66.7-74.1$ & 70.0 \\
Preanal length & 71.0 & $70.5-76.7$ & 72.5 \\
Head length & 12.2 & $10.6-14.7$ & 12.5 \\
& & \\
Head depth & 42.0 & $35.3-50.3$ & 43.1 \\
Head width & 100.0 & $81.4-106.3$ & 92.6 \\
Interorbital width & 33.0 & $21.8-28.3$ & 26.0 \\
Preorbital length & 34.0 & $33.3-48.0$ & 39.7 \\
Eye diameter & $7.6^{*}$ & $7.2-12.0$ & 9.4 \\
Mouth width & $44.4^{*}$ & $43.4-63.7$ & 52.1 \\
Internarial width & 22.0 & $18.1-24.2$ & 21.4 \\
\hline
\end{tabular}




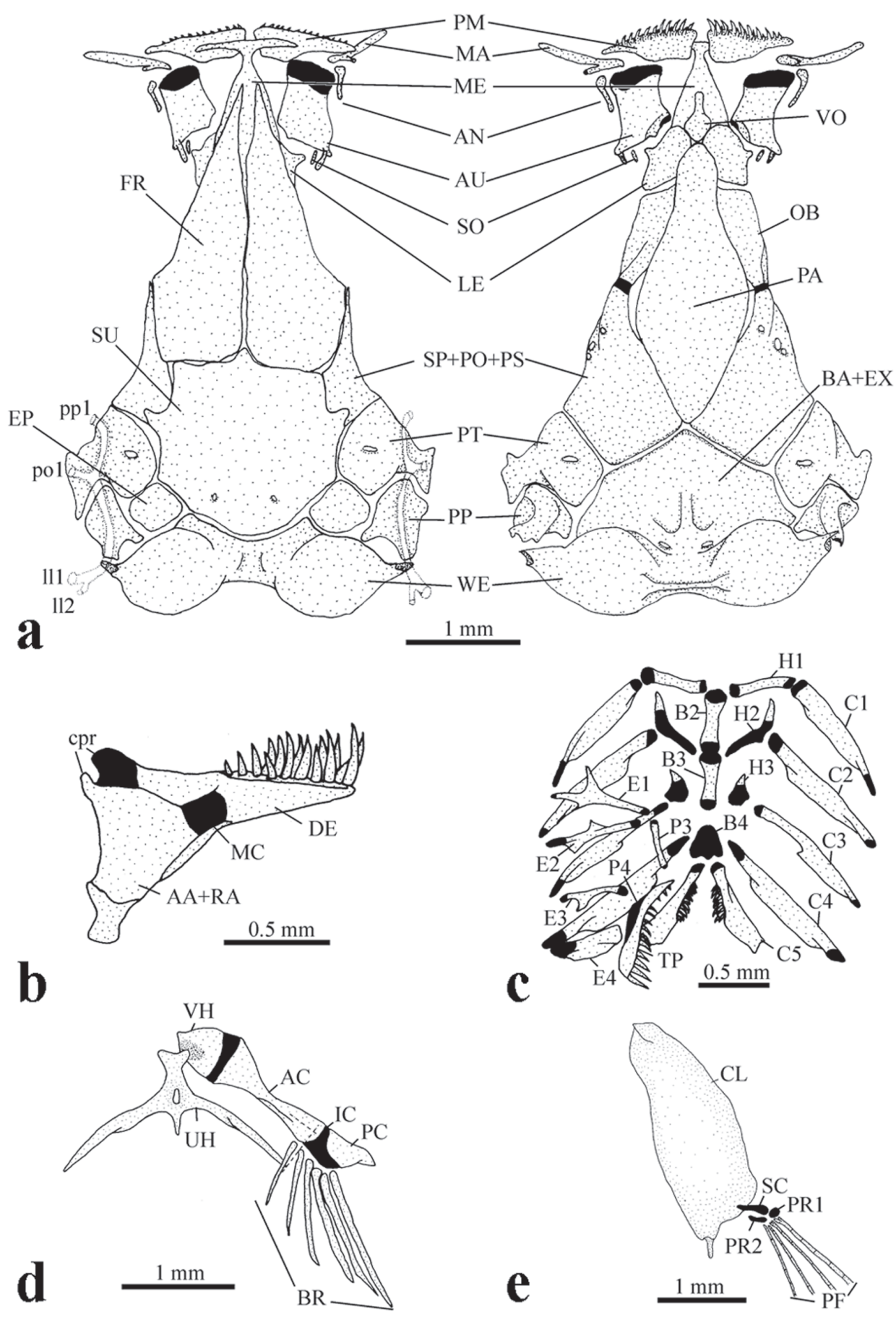

Fig. 5. Skeleton of Listrura camposi, MNRJ 37023, $35.7 \mathrm{~mm}$ SL. (a) Skull and Weberian capsule in dorsal (left) and ventral (right) views. (b) Lower jaw, left side; internal view. (c) Gill arches, dorsal view. Right dorsal elements not drawn. (d) Hyoid arch, left side: ventral view. Dashed lines indicate the tip of the lateral process of parurohyal in relation to ceratohyals. (e) Pectoral girdle, left side: ventral view. Legends: AA+RA - angulo-articular and retro-articular co-ossified, AC - anterior ceratohyal, AN - antorbital, AU - autopalatine, B2-4 - basibranchials 2 to 4, BA+EX - fused basioccipital-exoccipitals, BR - branchiostegal rays, C1-5 - ceratobranchials 1 to 5, CL - cleithrum, cpr - coronoid process, DE - dentary, E1-4 - epibranchials 1 to 4, EP - epioccipital, FR - frontal, H1-4 - hypobranchials 1 to 4, IC - interceratohyal cartilage, LE - lateral ethmoid, 111-2 - pores 1 and 2 of main lateral line, MA - maxilla, MC - Meckel cartilage, ME - mesethmoid, OB - orbitosphenoid, P3-4 - pharyngobranchials 3 and 4, PA parasphenoid, PC - posterior ceratohyal, PF - pectoral-fin rays, PM - premaxilla, PP - "posttemporosupracleithrum", pp1 - pore 1 of preopercular canal, po 1 - pore 1 of postotic canal, PT - pterotic, PR1-2 - proximal radials 1 and 2, RA - retro-articular, SC scapulocoracoid, SO - sesamoid supraorbital, SP+PO+PS - fused sphenotic-prootic-pterosphenoid, SU - parieto-supraoccipital, TP - tooth plate, UH - parurohyal, VH - ventral hypohyal, VO - vomer, WE - Weberian capsule. 
Basibranchial 1 absent (Fig. 5c). Basibranchials 2 and 3 cylindrical, interconnected by cartilages. Anteriormost border of basibranchial 2 and posteriormost border of basibranchial 3 with respective cartilages. Basibranchial 4 flattened and fully cartilaginous. Hypobranchial 1 cylindrical. Hypobranchials 2 and 3 flattened and cartilaginous with triangular anterolateral ossified process. Hypobranchial 4 absent. Ceratobranchials 1, 2, 3, and 4 cylindrical, with slight posterior laminar process. Ceratobranchial 5 with posterodorsally-oriented conical teeth on anterior half of mesial margin. All ceratobranchials with cartilages on tips, except ceratobranchial 5 without cartilage on posterior tip. Epibranchials 1, 2, and 3 thin; first and second with anterior and posterior processes, respectively, and third with curved posterior uncinate process. Epibranchial 4 cylindrical with large laminar process on posterior margin. Epibranchial 5 absent. Pharyngobranchials 1 and 2 absent. Pharyngobranchial 3 cylindrical. Pharyngobranchial 4 fully cartilaginous and fastened to tooth plate. Upper pharyngeal tooth plate with long ventromedially-oriented conical teeth.

Parurohyal with narrow pointed and elongated lateral processes reaching to posterior tip of anterior ceratohyal (Fig. 5d). Two small condyles on anterior region of parurohyal. Deep depression on ventral hypohyal for articulation with parurohyal condyle. Anterior ceratohyal cylindrical and constricted on central region. Posterior ceratohyal nearly triangular. Interceratohyal cartilage expanded on portion of branchiostegal rays.

Cleithrum flattened, slightly triangular and with large decalcified central region (Fig. 5e). Scapulocoracoid fully cartilaginous. Proximal radial 1 rounded and proximal radial 2 elongate; both fully cartilaginous.

Caudal skeleton partly compact (Fig. 4). Parhypural and hypurals 1-2 fused. Hypurals 1-2 and Hypurals 3-5 separated. Uroneural entirely fused to compound centrum. Preural 1ural 1 compound with vestigial neural arch.

Color in alcohol. Dorsal half of trunk and caudal peduncle with irregular or roundish, partly coalescent, dark marks (Fig. 1). Marks darkest and densest along lateral midline, forming longitudinal stripe extending from posterior margin of head to beginning of caudal peduncle; in some specimens extending posteriorly onto part or whole of caudal peduncle as fine line. Midlateral dark stripe nearly continuous in some specimens, interrupted as series of individual dark spots in others. Myomeres on caudal peduncle partly and irregularly outlined by slanted dark lines. Ventral part of flank and abdomen white or with few scattered dark spots, denser posteriorly. Pectoral fin white or with faint dark streaks dorsally along margin of first ray. Dark concentration alongside base of anal fin, forming short dark band in some specimens. Remainder of anal fin without dark pigment. Region of procurrent caudal-fin rays with sparse dark fields, denser on dorsal series. Caudal fin with elongate dark fields on central portions of principal rays, forming spotted pattern or faint irregular vertical stripes.
Dorsal surface of head with irregular covering of semicoalesced dark marks (Fig. 2a). Marks densest on snout, especially around posterior nostrils, extending posteroventrally onto base of both opercular and interopercular patches of odontodes. Some specimens with pigment on snout uniform. Region of neurocranium darker than rest of head, due mostly to brain pigment seen by transparency. White or less darkly-pigmented area ventrolateral to eye. Margins of posterior nostrils and sensory pores finely delineated in white. Basal portion of maxillary barbel with elongate scattering of dark chromatophores along dorsal surface of anterior margin; ventral surface with sparse dark fields near base. Similar pattern of dark pigmentation on nasal and rictal barbels, but faintest on latter. Ventral side of head less darkly pigmented than dorsal surface, with irregular field of dark chromatophores over mental region, extending in curved paths posteriorly along bases of branchiostegal rays and then ventrally joining dark covering of interopercular patch of odontodes (Fig. 2b). Lower lip white, with dark spot at symphysis in some specimens.

Color in life. Entire ground color of body and head yellowish, slightly reddish on branchial region and alongside ventral part of vertebral column due to blood seen by transparency (Fig. 1). Dark brain pigment more visibly pronounced than in preserved specimens, probably due to increased transparency of integument in life. Fins mostly hyaline. Dark pigmentation otherwise similar to that in preservative (see above).

Distribution and habitat notes. Listrura camposi is known to occur in two small streams tributaries to rio Juquiá, rio Ribeira de Iguape basin, São Paulo State: ribeirão Poço Grande, município de Juquiá (type locality), and a tributary to rio Itariri, município de Pedro de Toledo (Fig. 6). Approximately 37 km separate the two localities. However, the area of the type locality is presently much degraded, due to intense human activity in the region (O.T. Oyakawa, pers. comm.; MCCP, pers. obs.), and there seems to be little hope of any surviving populations of $L$. camposi there.

The specimens of Listrura camposi from the tributary to the rio Itariri were collected in a narrow (about $1 \mathrm{~m}$ wide) and shallow (about $10 \mathrm{~cm}$ deep) clear-water pool contiguous to the stream, covered with a dense layer of leaf litter on bottom (Fig. 7) and crossing under a small road before joining the rio Itariri. Although the mountain slope is covered with dense Atlantic forest, a great portion of the stream in the lowland plain area, where most of the L. camposi specimens were caught, is devoid of riparian protection. Individuals were concentrated on the stretch immediately below the steepslope portion of the stream. The species seems to be restricted to the interface between the fast-flowing, high energy sector and the lowland slow-current portion of the stream. Some specimens were captured in a small pool just within the fastflowing sector, in a dense layer of leaf litter, but none in similar 
pools further upstream. Specimens were captured mostly in leaf litter in shaded areas and amidst roots of emerging vegetation in sand-clay substrate, in sun-exposed areas.

Listrura camposi specimens are locally abundant, although their area of occupancy is extremely restricted, with the stream and the contiguous pool in this stretch not exceeding $50 \mathrm{~m}^{2}$. Gymnotus pantherinus (Steindachner), Hollandichthys multifasciatus (Eigenmann \& Norris), and Atlantirivulus santensis (Köhler) were the only fishes collected with L. camposi. Copepods, insect larvae and mites were found on stomach contents of some CS specimens, as previously observed for L. tetraradiata by Landim \& Costa (2002).

Material examined. Brazil. São Paulo State. MZUSP 3426, holotype, 38.0 mm SL, município de Juquiá, ribeirão Poço Grande, tributary to right margin of rio Juquiá, itself tributary to rio Ribeira, rio Ribeira de Iguape basin, approximately $24^{\circ} 15^{\prime} \mathrm{S} 47^{\circ} 37^{\prime} \mathrm{W}$. MNRJ 37023, 6 (2 CS), 29.6-43.4 mm SL; MNRJ 33031, 18 (1 CS), 28.4$50.0 \mathrm{~mm}$ SL; and MZUSP 95189, 25 (2 CS), 20.7-46.4 mm SL, município de Pedro de Toledo, small stream tributary to rio Itariri, itself tributary to rio Juquiá, rio Ribeira de Iguape basin, just upstream from small road near to protected area "Parque Estadual da Serra do Mar - Núcleo Pedro de Toledo", 24¹5'06.4”S $47^{\circ} 14^{\prime} 53.3^{\prime \prime} \mathrm{W}$.

\section{Discussion}

\section{About taxonomic status}

The taxonomy of Listrura has been developed in chronic paucity of study material. As expected, decisions about taxonomic boundaries are often less than ideal. This is an unavoidable consequence of the limited information on intraspecific variation. Listrura camposi, known from a single specimen for several decades (currently with a high degree of deterioration), is the prime example of such scenario. Only in recent years the situation has begun to change, with discoveries of some previously unknown populations and species. The rediscovery of $L$. camposi reported here is a fitting example of such trend. The species was the first Listrura to be collected and described, and the lack of basic information was vexing, hindering proper taxonomic characterization of related forms discovered subsequently.

A case in question is the sample of Listrura reported by Nico \& de Pinna (1996) from the region of the Brazilian city of Florianópolis, Santa Catarina State. The presence of three unbranched pectoral-fin rays in those specimens was a major factor in their identification as L. camposi, the only species in the genus with such characteristic (Miranda-Ribeiro, 1957; de Pinna, 1988; de Pinna \& Wosiacki, 2002). The new material reported in this paper shows that a fourth ray may be present in some specimens and that pectoral fin-ray count is variable (sometimes in the same individual; $c f$. Description above). On the other hand, the constancy of some characters in the large sample of $L$. camposi now available permits a more conclusive evaluation of some differences found between the two populations. Listrura camposi displays both tips of Meckel

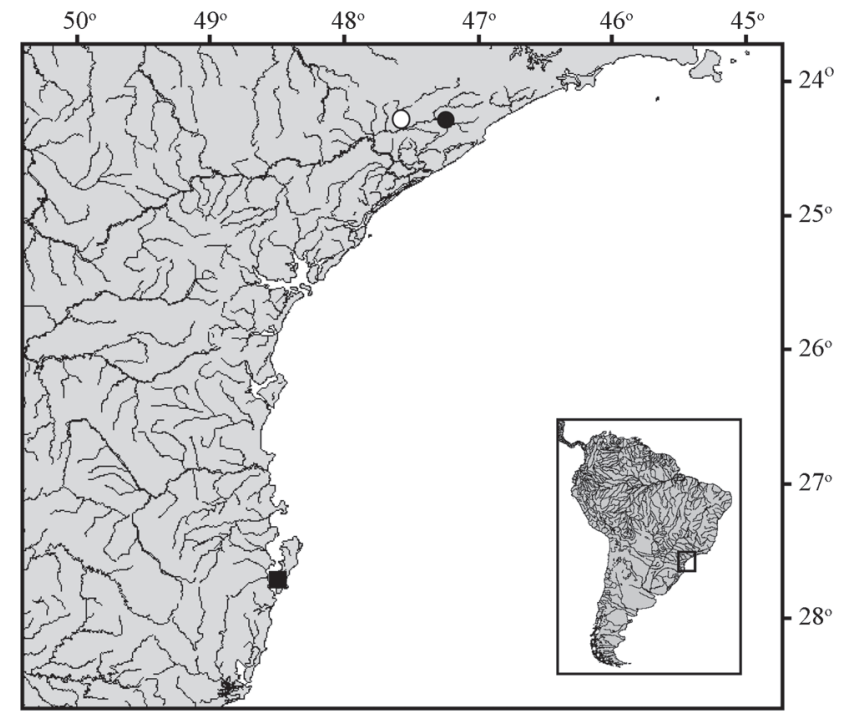

Fig. 6. Geographic distribution of Listrura camposi (circles) and Listrura sp. (square) from município de Florianópolis; Southeastern Brazil, Santa Catarina to São Paulo States. Open circle indicates the type locality of L. camposi.

cartilage with similar height (Fig. 5b), while in the population from Florianópolis the tip in contact with angulo-articular is clearly deeper than the tip in contact with dentary. On a similar fashion, the abrupt depression on dorsal margin of the quadrate present in L. camposi (Fig. 3) contrasts with the very slight depression, practically absent in population from

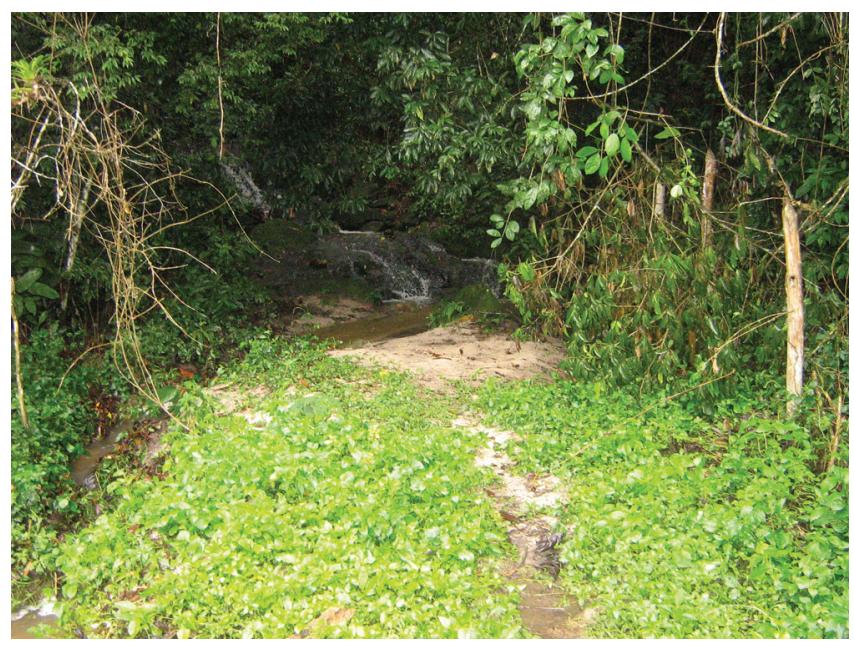

Fig. 7. Photograph of small stream tributary to rio Itariri, itself tributary to rio Juquiá, rio Ribeira de Iguape basin, $24^{\circ} 15^{\prime} 06.4^{\prime \prime} \mathrm{S} 47^{\circ} 14^{\prime} 53.3^{\prime \prime} \mathrm{W}$, locality of the newly-discovered population of Listrura camposi. 
Florianópolis. Additionally, the interopercular patch of odontodes in the latter reaches a vertical through the articular condyle of interopercle. In L. camposi, in contrast, this patch is shorter, not reaching that landmark (Fig. 3). Those three characters indicate that the population of Listrura from Florianópolis may not be conspecific with L. camposi. Confirmation of that, as usual in the genus, will require collection of additional specimens from the population from Florianópolis.

The osteological data also reveal at least two significant features with potential phylogenetic information. Usually in trichomycterids, the posterolateral process of autopalatine is aligned in the same plane of the bone. Listrura camposi (also recently reported to $L$. costai by Villa-Verde et al., 2012) shows a peculiar condition, in which the process is dorsally curved in a perpendicular plane to the bone (Fig. 5a). In fact, all Listrura herein examined display this condition. It can certainly be considered as a synapomorphic character to the genus. By contrast, L. camposi displays a putative plesiomorphic condition in comparison to remaining glanapterygines. A fusion between all elements of the caudal skeleton has being considered as a synapomorphic character for Glanapteryginae (e.g., de Pinna, 1988, 1989, 1998). In L.camposi, hypurals 3-5 are separated from hypurals 1-2 (Fig. $5 b)$. This could be either a plesiomorphic condition or a reversal in L. camposi, pending resolution of the phylogenetic relationships among species of Listrura.

\section{About Conservation status}

All species of Listrura have restricted geographic distributions and are narrowly associated with small forested streams (Nico \& de Pinna, 1996; Landim \& Costa, 2002; de Pinna \& Wosiacki, 2002; Villa-Verde \& Costa, 2006). Of the six valid species of Listrura, three are included in Brazilian lists of threatened species, with L. camposi considered as Critically Endangered and L. nematopteryx and L. tetraradiata as Vulnerable (MMA, 2004; Rosa \& Lima, 2005, 2008). Listrura costai was suggested as Vulnerable by Villa-Verde et al. (2012), but not included in any list yet. On the other hand, the conservation status for the other two species, L. boticario and L. picinguabae, is undetermined (Menezes et al., 2007). The latter two species have at least part of their populations within official preservation areas, which represent some measure of protection for their immediate survival.

The failure in locating additional specimens of Listrura camposi during almost seven decades of intense ichthyological exploration in the rio Ribeira basin is partly a consequence of the destruction of its preferred habitat by human occupation (Rosa \& Lima, 2008), and partly of its unusual habitat. Although the newly-discovered population seems healthy and is located close to a protected area (Parque Estadual Serra do Mar - Pedro de Toledo), it is crossed by a dirt road and surrounded by sparse settlements which draw water from the streams. The population seems particularly vulnerable to environmental disturbance and, consequently, local extirpation.

Lima (in Rosa \& Lima, 2008) classified Listrura camposi as Critically Endangered, based on IUCN criteria A2ace; B2ab(iii) (IUCN, 2011). Application of criterion A, however, was mistaken since there are no studies reporting population decrease in L. camposi. Nevertheless, the overall ranking is accurate, for the following reasons: a) the area of occupancy of the species is less than $10 \mathrm{~km}^{2}$ - criterion CR B2. b) the species is severely fragmented, with the two punctual known localities separated by $c a$. $40 \mathrm{~km}$ - criterion CR B2a. c) the population from the type locality is within a progressively degrading area and is likely extinct - criterion CR B2b(iv). Therefore, we strongly recommend incorporation of the area encompassing the population of L. camposi from rio Itariri into the legal boundaries of the Parque Estadual da Serra do Mar - Pedro de Toledo, in order to protect the only current known population of the species.

Comparative Material. Listrura boticario. Brazil. Paraná State. MHNCI 11689, 6 (1 CS), 26.1-34.3 mm SL; and MNRJ 32444, 21 (2 CS), 16.2-40.2 mm SL, município de Antonina, small stream tributary to rio Copiuva, rio Cachoeira basin, $25^{\circ} 19^{\prime} 25.1^{\prime \prime S}$ 04840’31.0”W. MHNCI 11690, 2 (1 CS), 38.0-40.5 mm SL, small abandoned meander of an unnamed river, rio Cachoeira basin, 25²2'45.22”S 4842'40.69'W. MNRJ 32442, 1, 37.2 $\mathrm{mm}$ SL; and MZUSP 69573, holotype, $36.7 \mathrm{~mm} \mathrm{SL}$, município de Guaraqueçaba, rio da Figueira, rio Morato basin, $25^{\circ} 10^{\prime} 43.6$ "S 048 18 '42.4”W. Listrura costai. Brazil. Rio de Janeiro State. MNRJ 31917, 31.3 mm SL, município de Angra dos Reis, small unnamed stream close to the road RJ-155 (Angra-Lídice), rio Jurumirim basin, 22 55 '24.7"S 044¹8'51.4”W. MNRJ 31535, 3 (2 CS) 20.4-32.1 mm SL; MNRJ 31918, 5, 14.9-29.0 mm SL; UFRJ 7214, 3, 28.1-33.5 mm SL; UFRJ 7215, 4, 26.0-32.0 mm SL; and UFRJ 6577, 3 CS, 32.0-34.3 mm SL, município de Angra dos Reis, swamp area close to the road RJ-155 (Angra-Lídice), about $1 \mathrm{~km}$ from road BR-101, rio Jurumirim basin, 22 ${ }^{\circ} 55^{\prime} 24.7$ ' $\mathrm{S}$ 044¹8'37.5"W. Listrura nematopteryx. Brazil. Rio de Janeiro State. MNRJ 10970, 8 (1 CS) paratypes, 25.1-30.9 mm SL; UFRJ 0707, 9, 20.1-30.5 mm SL; and UFRJ 5952, 5 CS, 21.0$29.4 \mathrm{~mm}$ SL, município de Magé, marsh adjacent to rio Imbariê, rio Estrela basin, 22०36'36"S 043011'26"W. Listrura picinguabae. Brazil. São Paulo State. MCP 38921, 2, paratypes, 31.8-42.5 mm SL; UFRJ 6111, holotype, $48.6 \mathrm{~mm} \mathrm{SL;} \mathrm{UFRJ}$ 5948, 1, paratype, $35.5 \mathrm{~mm}$ SL; UFRJ 5949, 2, paratypes, 24.3 $32.3 \mathrm{~mm}$ SL; UFRJ 5950, 15, paratypes, 29.4-45.3 mm SL; UFRJ 5951, 4 CS, paratypes, 31.3-35.5 mm SL; UFRJ 5991, 2 CS, paratypes, 26.3-31.9 mm SL; and UFRJ 6138, 5 CS, paratypes, 36.0-50.2 mm SL, município de Ubatuba, small stream, rio da Fazenda basin, $23^{\circ} 20^{\prime}$ S $044^{\circ} 45^{\prime}$ W. Listrura sp. Brazil. Santa Catarina State. MZUSP 63440, 1, 39.0 mm SL; UFRJ 1278, 1, $39.5 \mathrm{~mm}$ SL; and UFRJ 1279, 1 CS, $35.1 \mathrm{~mm}$ SL, município de Florianópolis, Ribeirão da Ilha, 27² ' S 048 32'W. Listrura tetraradiata Brazil. São Paulo State. MNRJ 31534, 17 (4 CS), paratypes, 15.5-39.9 mm SL; MNRJ 39068, 6, 29.2-36.7 mm SL; MZUSP 52572, holotype, $37.3 \mathrm{~mm}$ SL; UFRJ 4586, 17, paratypes, 10.8-43.1 mm SL; UFRJ 4588, 3 CS, paratypes, 21.1$40.6 \mathrm{~mm}$ SL; and UFRJ 4590, 7, paratypes, 24.5-44.4 mm SL, município de Saquarema, rio da Represa, rio Ibicuíba basin, approximately $22^{\circ} 56^{\prime} \mathrm{S} 042^{\circ} 31^{\prime} \mathrm{W}$. 


\section{Acknowledgments}

Thanks to Cristiano Moreira, Daniel Almeida, Marcelo R. Britto, Osvaldo T. Oyakawa, Paulo A. Buckup and Renata Bartolette for assistance in the field. Special words of gratitude go to Osvaldo T. Oyakawa for information about conservation status of the type locality of Listrura camposi, to Wilson Costa and Vinícius Abilhoa for the loan of comparative material, and to Cristiano Moreira for the photo of live specimen. This study was supported by CNPq (Conselho Nacional de Desenvolvimento Científico e Tecnológico Ministério de Ciência, Tecnologia e Inovação, Proc.\#474788/ 2006-7, 502975/2005-9 and 307207/2009-9), and ACSI (All Catfish Species Inventory NSF 0315963). Collections were made under permits 072/2006 - DIFAP/IBAMA (Instituto Brasileiro do Meio Ambiente e dos Recursos Naturais Renováveis - Ministério do Meio Ambiente, dos Recursos Hídricos e da Amazônia Legal [Brazilian Federal Government]), and 44.661/2005 IF-SP (Instituto Florestal, São Paulo).

\section{Literature Cited}

Adriaens, D., J. N. Baskin \& H. Coppens. 2010. Evolutionary morphology of trichomycterid catfishes: about hanging on and digging in. Pp. 337-362. In: Nelson, J. S., H.-P. Schultze \& M. V. H. Wilson (Eds.). Origin and Phylogenetic Interrelationships of Teleosts. München, Verlag Dr. Friedrich Pfeil.

Arratia, G. \& L. Huaquín. 1995. Morphology of the lateral line system and of the skin of diplomystid and certain primitive loricarioid catfishes and systematic and ecological considerations. Bonner Zoologische Monographien, 36: 1-109.

Bizerril, C. R. S. F. 1994. Descrição de uma nova espécie de Trichomycterus (Siluroidei, Trichomycteridae) do Estado de Santa Catarina, com uma sinopse da composição da família Trichomycteridae no leste Brasileiro. Arquivos de Biologia e Tecnologia, 37: 617-628.

Bockmann, F. A., L. Casatti \& M. C. C. de Pinna. 2004. A new species of trichomycterid catfish from the Rio Paranapanema basin, southeastern Brazil (Teleostei: Siluriformes), with comments on the phylogeny of the family. Ichthyological Exploration of Freshwaters, 15: 225-242.

Britski, H. A. 1969. Lista dos tipos de peixes das coleções do Departamento de Zoologia da Secretaria da Agricultura de São Paulo. Papeis Avulsos do Departamento de Zoologia da Universidade de São Paulo, 22: 197-215.

Burgess, W. E. \& L. Finley. 1996. An atlas of freshwater and marine catfishes: Update. Tropical Fish Hobby, 1996: 163-174.

Costa, W. J. E. 1992. Description de huit nouvelles espèces du genre Trichomycterus (Siluriformes : Trichomycteridae), du Brésil oriental. Revue Française d'Aquariologie et Herpétologie, 18: 101-110.

Datovo, A. \& F. A. Bockmann. 2010. Dorsolateral head muscles of the catfish families Nematogenyidae and Trichomycteridae (Siluriformes: Loricarioidei): comparative anatomy and phylogenetic analysis. Neotropical Ichthyology, 8: 193-246.

Ferraris Jr., C. J. 2007. Checklist of catfishes, recent and fossil (Osteichthyes: Siluriformes), and catalogue of siluriform primary types. Zootaxa, 1418: 1-628.

IUCN Standards and Petitions Subcommittee. 2011. Guidelines for Using the IUCN Red List Categories and Criteria, Version 9.0,
Standards and Petitions Subcommittee, 87p. Available from: http://www.iucnredlist.org/documents/RedListGuidelines.pdf (October 30, 2012).

Landim, M. I. \& W. J. E. M. Costa. 2002. Listrura tetraradiata (Siluriformes: Trichomycteridae): a new glanapterygine catfish from the southeastern Brazilian coastal plains. Copeia, 2002: 152-156.

Menezes, N. A., S. H. Weitzman, O. T. Oyakawa, F. C. T. Lima, C. M. C. Castro \& M. J. Weitzman. 2007. Peixes de água doce da Mata Atlântica: lista preliminar das espécies e comentários sobre conservação de peixes de água doce neotropicais / Freshwater fishes of Mata Atlântica: list of species and comments on conservation of neotropical freshwater fishes. Museu de Zoologia da Universidade de São Paulo, 408p.

Miranda-Ribeiro, P. 1957. Notas para estudo dos Pygidiidae brasileiros (Pisces - Pygidiidae) VI. Papeis Avulsos do Departamento de Zoologia da Secretaria de Agricultura de São Paulo, 13: 71-73.

Miranda-Ribeiro, P. 1962. Notas para estudo dos Pygidiidae brasileiros (Pisces - Pygidiidae) VII. Boletim do Museu Nacional, 242: 1-4.

MMA - Ministério do Meio Ambiente. 2004. Lista Nacional das Espécies de Invertebrados Aquáticos e Peixes Ameaçados de Extinção. Instrução Normativa $n^{\circ}$ 5, 21 de Maio de 2004. Pp. 136-141. In: Diário Oficial da União, seção 1, nº 102, sextafeira, 28 de maio de 2004. Imprensa Nacional.

Nico, L. G. \& M. C. C. de Pinna. 1996. Confirmation of Glanapteryx anguilla (Siluriformes, Trichomycteridae) in the Orinoco River Basin, with notes on the distribution and habitats of the Glanapteryginae. Ichthyological Exploration of Freshwaters, 7: 27-32.

de Pinna, M. C. C. 1988. A new genus of trichomycterid catfish (Siluroidei, Glanapteryginae), with comments on its phylogenetic relationships. Revue suisse de Zoologie, 95: 113-128.

de Pinna, M. C. C. 1989. Redescription of Glanapteryx anguilla, with notes on the phylogeny of Glanapteryginae (Siluriformes: Trichomycteridae). Proceeding of the Academy of Natural Sciences of Philadelphia, 141: 361-374.

de Pinna, M. C. C. 1998. A new species of the genus Glanapteryx (Siluriformes: Trichomycteridae). Proceedings of the Biological Society of Washington, 111: 35-42.

de Pinna, M. C. C. \& A. L. Kirovsky. 2011. A new species of sanddwelling catfish, with a phylogenetic diagnosis of Pygidianops Myers (Siluriformes: Trichomycteridae: Glanapteryginae). Neotropical Ichthyology, 9: 493-504.

de Pinna, M. C. C. \& W. B. Wosiacki. 2002. A new interstitial catfish of the genus Listrura from Southern Brazil (Siluriformes: Trichomycteridae: Glanapteryginae). Proceedings of the Biological Society of Washington, 115: 720-726.

de Pinna, M. C. C. \& W. Wosiacki. 2003. Family Trichomycteridae (pencil or parasitic catfishes). Pp. 270-290. In: Reis, R. E., S. O. Kullander \& C. J. Ferraris Jr. (Eds.). Check list of the freshwater fishes of South and Central America. Porto Alegre, Edipucrs.

Rosa, R. S. \& F. C. T. Lima. 2005. Peixes. Pp. 67-81. In: A. B. M. Machado, C. S. Martins \& G. M. Drummond (Eds.). Livro da Fauna Brasileira Ameaçada de Extinção. Belo Horizonte, Fundação Biodiversitas.

Rosa, R. S. \& F. C. T. Lima. 2008. Os peixes brasileiros ameaçados de extinção. Pp. 9-285. In: A. B. M. Machado, G. M. Drummond \& A. P. Paglia (Eds.). Livro Vermelho da Fauna Brasileira Ameaçada de Extinção, Volume II. Brasília, Ministério do Meio Ambiente. 
Taylor, W. R. \& G. C. van Dyke. 1985. Revised procedures for staining and clearing small fishes and other vertebrates for bone and cartilage study. Cybium, 9: 107-109.

Villa-Verde, L. \& W. J. E. M. Costa. 2006. A new glanapterygine catfish of the genus Listrura (Siluriformes: Trichomycteridae) from the southeastern Brazilian coastal plains. Zootaxa, 1142: 43-50.

Villa-Verde, L., H. Lazzarotto \& S. M. Q. Lima. 2012. A new glanapterygine catfish of the genus Listrura (Siluriformes: Trichomycteridae) from southeastern Brazil, corroborated by morphological and molecular data. Neotropical Ichthyology, 10: 527-538.

Wosiacki, W. B. \& M. C. C. de Pinna. 2007. Trichomycteridae: Glanapteryginae. Pp. 74-75. In: Buckup, P. A., N. A. Menezes \& M. S. Ghazzi (Eds.). Catálogo das espécies de peixes de água doce do Brasil. Rio de Janeiro, Museu Nacional.

Submitted April 15, 2012

Accepted December 26, 2012 by Paulo H. F. Lucinda

Published March 31, 2013 